\title{
Diagnostic value of serum pepsinogen $C$ in patients with raised serum concentrations of pepsinogen $\mathrm{A}$
}

\author{
I Biemond, J Kreuning, J B M J Jansen, C B H W Lamers
}

\begin{abstract}
Hypopepsinogenaemia $A$ is often found in patients with gastric atrophy and gastric surgery. In these conditions serum pepsinogen $C$ provides additional diagnostic information, especially when expressed as pepsinogen $A: C$ ratio. Hyperpepsinogenaemia $A$ has been shown in patients with duodenal ulcer disease, Zollinger-Ellison syndrome, hypertrophic gastropathy, chronic renal failure, and during omeprazole treatment. As patients with hyperpepsinogenaemia $A$ often overlap in symptoms, endoscopical findings, and serum gastrin values, this study has evaluated whether measurement of serum pepsinogen $C$ in subjects with hyperpepsinogenaemia $\mathbf{A}$ can help in differentiating clinical conditions. Serum concentrations of pepsinogen $A$ and $C$ were measured in serologically Helicobacter pylori negative blood transfusion donors (127) as reference population, and in patients with Zollinger-Ellison syndrome (24), duodenal ulcer (50), hypertrophic gastropathy (5), and chronic renal failure (50), and also in reflux oesophagitis patients on longterm omeprazole treatment (28). A low pepsinogen A:C ratio was found in all patients with hypertrophic gastropathy. A pepsinogen $A: C$ ratio above the critical value of 4.7 was found in $14(70.0 \%)$ of the Zollinger-Ellison patients, two $(9.5 \%)$ of the duodenal ulcer patients, $11(25.6 \%)$ of the patients with chronic renal failure, and in one $(7 \cdot 1 \%)$ of the patients receiving longterm omeprazole treatment. In fact, all but three hyperpepsinogenaemia $A$ patients with a pepsinogen A:C ratio greater than 4.7 and normal renal function had the ZollingerEllison syndrome. In patients with hyperpepsinogenaemia A, a low pepsinogen A:C ratio may point to hypertrophic gastropathy, while a pepsinogen $A: C$ ratio greater than 4.7 is suggestive for the Zollinger-Ellison syndrome. (Gut 1993; 34: 1315-1318)
\end{abstract}

Serum pepsinogen A and C values, formerly called pepsinogen I and II, respectively, have been determined in various gastric disorders. Hypopepsinogenaemia $\mathrm{A}$ has been found to be associated with gastric atrophy ${ }^{1-3}$ and gastrectomy..$^{3-7}$ In these conditions serum pepsinogen $\mathrm{C}$ provided additional diagnostic information, especially when expressed as pepsinogen A:C ratio. ${ }^{1-3}$ Hyperpepsinogenaemia $A$ has often been seen in duodenal ulcer, ${ }^{8}$ Zollinger-Ellison syndrome, ${ }^{10}$ hypertrophic gastropathy," and chronic renal failure. ${ }^{12-14}$ High values of serum pepsinogen $\mathrm{A}$ have also been found during omeprazole treatment. ${ }^{15-17}$ As it is unknown whether measurement of serum pepsinogen $\mathrm{C}$ can help in the differentiation of patients with hyperpepsinogenaemia $A$, serum concentrations of both pepsinogens were determined in patient groups known to have an increased incidence of hyperpepsinogenaemia A.

\section{Methods}

\section{SUBJECTS}

Blood transfusion donors, serologically negative for Helicobacter pylori, ${ }^{18}$ (87 men, 40 women; mean (SD) age: 35 (10) years) were used as the reference population. Furthermore, 24 patients with Zollinger-Ellison syndrome (15 men, nine women; age: 50 (10) years) were investigated. Twenty of them had an abnormal high increase ( $>400 \mathrm{ng} / \mathrm{l}$ ) of serum gastrin after provocation with $1 \mathrm{CU} / \mathrm{kg}$ secretin GIH. Twelve of these 20 patients suffered from the MEN I syndrome. Metastases were detected in 13 of 24 patients, including those with a negative secretin test. Five patients with endoscopically and histologically proved hypertrophic gastropathy (three men, two women; age: 52 (13) years), 50 patients with an endoscopically proved duodenal ulcer (43 men, seven women; age: 52 (14 years), 50 patients with chronic renal failure on regular haemodialysis treatment ( 31 men, 19 women; age: 52 (16) years), and 28 patients with reflux oesophagitis treated with omeprazole for three months (13 men, 15 women; age: 62 (14) years) were investigated. None of these patients had had previous gastric surgery.

\section{MEASUREMENTS}

Serum pepsinogen $A$ and pepsinogen $C$ were measured by sensitive and specific radioimmunoassays as described previously. ${ }^{19}$ In brief, antibodies to pepsinogen $\mathrm{A}$ and pepsinogen $C$ were raised in goats against pepsinogen $A$ and pepsinogen $\mathrm{C}$ purified from human gastric resection specimens and were used in final dilutions of $1: 300000$ and 1:200000, respectively. The antibody to pepsinogen A showed no cross reactivity with pepsinogen $C$, whereas the antibody to pepsinogen $\mathrm{C}$ did not cross react with pepsinogen A. Purified human pepsinogen A and pepsinogen $C$ were coupled to ${ }^{125} I$ by the chloramine $\mathrm{T}$ method and used as label in the assays. Purified human pepsinogen $A$ and pepsinogen $C$ were also used as standard preparations. Serum samples were diluted 10 -fold for pepsinogen $\mathrm{A}$ and fivefold for pepsinogen $\mathrm{C}$ and incubated with labelled pepsinogen and antibody in a final volume of $1 \mathrm{ml}$ for four days at $4^{\circ} \mathrm{C}$. Free pepsinogen was subsequently separated from antibody bound pepsinogen by a double antibody solid phase technique and the 
pellets were counted in a gammascintillation counter. Intra-assay variations vary from three to 10 per cent for pepsinogen $A$ and 13 to 15 per cent for pepsinogen $\mathrm{C}$. The detection limit for the pepsinogen $A$ radioimmunoassay was $0 \cdot 12$ $\mu \mathrm{g} / \mathrm{l}$ and for the pepsinogen $\mathrm{C}$ radioimmunoassay $1.8 \mu \mathrm{g} / \mathrm{l}$. Dilution curves of a serum sample containing high concentrations of pepsinogens were parallel to the standard curve. The squared limits of the $95 \%$ confidence intervals for the mean of the square root transformed values of the blood transfusion donors and resulted in the upper and lower normal value for serum pepsinogen $A$ and $C$. For the pepsinogen $A: C$ ratio these limits and the mean have been calculated with values transformed by the decadic logarithm.

\section{STATISTICS}

Values of serum pepsinogens are given as means and standard deviations (SD). Analysis of variance and the Newman-Keuls procedure were applied to measure the statistical significance of means from different diagnostic categories. To discriminate patients with Zollinger-Ellison syndrome from other subjects, the mean of both respective group means was chosen as the critical value of the pepsinogen A:C ratio. The $\chi^{2}$ with Yates's correction was applied to test the significance of differences between frequencies.

Figure 1: Shaded area: the normal range of serum pepsinogen $C(2-24 \mu g / l)$. The subjects were grouped into normal (including low values) and high values (>95 $\mu \mathrm{g} / \mathrm{l}$ ) of serum pepsinogen A. Values of serum pepsinogen $C$ of blood transfusion donors $(B T D)$ of patients with hypertrophic gastropathy $(H G)$, with Zollinger-Ellison syndrome (ZES), with duodenal ulcer $(D U)$, with chronic renal failure (CRF), and of patients with reflux oesophagitis treated with omeprazole for three months $(O M E)$.

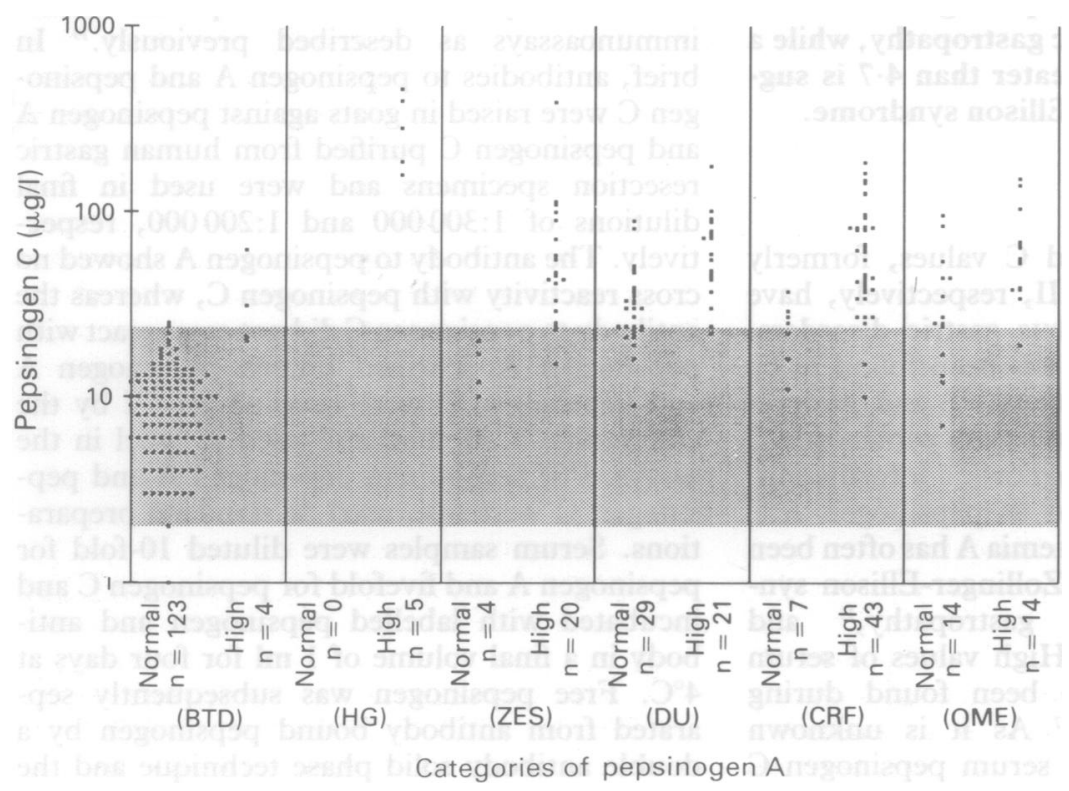

with Zollinger-Ellison syndrome, 21 of 50 (42\%) of patients with duodenal ulcer, 43 of $50(86 \%)$ of patients with chronic renal failure, and 14 of 28 (50\%) of patients with reflux oesophagitis on longterm omeprazole treatment had a raised serum pepsinogen A concentration above 95 $\mu \mathrm{g} / \mathrm{l}$. Figure 1 shows the individual values of serum pepsinogen $C$ and normal range (2-24 $\mu \mathrm{g} / \mathrm{l})$ in subjects with normal and raised serum pepsinogen A concentrations. High values of serum pepsinogen $C$ were frequently found in all groups of patients with hyperpepsinogenaemia A. In the group of subjects with raised concentrations of serum pepsinogen A, four blood transfusion donors had a mean (SD) serum pepsinogen C concentration of $34(20) \mu \mathrm{g} / \mathrm{l}, 20$ patients with Zollinger-Ellison syndrome of 73 (81) $\mu \mathrm{g} / \mathrm{l}, 21$ duodenal ulcer patients of 65 (34) $\mu \mathrm{g} / \mathrm{l}, 43$ patients with chronic renal failure of 69 (42) $\mu \mathrm{g} / \mathrm{l}$, and 14 patients with reflux oesophagitis on longterm omeprazole treatment of 66 (39) $\mu \mathrm{g} / \mathrm{l}$. The mean of serum pepsinogen $\mathrm{C}$ values in five hypertrophic gastropathy patients with hyperpepsinogenaemia A was 296 (131) $\mu \mathrm{g} / \mathrm{l}$. Analysis of variance (ANOVA) of serum pepsinogen $C$ values followed by the NewmanKeuls procedure showed that the mean value of hypertrophic gastropathy differed significantly from the other diagnostic groups. In patients with hyperpepsinogenaemia A raised serum pepsinogen $C$ values $(>24 \mu \mathrm{g} / \mathrm{l})$ were found in two $(50 \%)$ of blood transfusion donors, in all patients with hypertrophic gastropathy, in 17 (85\%) of patients with Zollinger-Ellison syndrome, 19 (90.5\%) with duodenal ulcer patients, $41(95 \cdot 3 \%)$ with chronic renal failure, and 13 $(92.9 \%)$ on longterm omeprazole treatment.

In subjects with hyperpepsinogenaemia A, four blood transfusion donors had a mean (SD) pepsinogen A:C ratio of $3.9(1.9)$, five patients with hypertrophic gastropathy of $1 \cdot 2(0 \cdot 3), 20$ patients with Zollinger-Ellison syndrome of 5.9 $(2 \cdot 4), 21$ duodenal ulcer patients of $2 \cdot 6(1 \cdot 3), 43$ patients with chronic renal failure of $4 \cdot 2(2 \cdot 1)$, and in 21 patients with reflux oesophagitis on longterm omeprazole treatment of $2.9(1 \cdot 5)$. ANOVA of the pepsinogen A:C ratio followed by the Newman-Keuls procedure showed that the mean value of hypertrophic gastropathy differed significantly from those of patients with Zollinger-Ellison syndrome and chronic renal failure. The mean value of Zollinger-Ellison patients differed significantly from those of all other patient groups.

Low pepsinogen $\mathrm{A}: \mathrm{C}$ ratios occurred in all patients with hypertrophic gastropathy, in eight $(38 \cdot 1 \%)$ with duodenal ulcer patients, in one $(2 \cdot 3 \%)$ patient with chronic renal failure, and in five $(35 \cdot 7 \%)$ patients on longterm omeprazole treatment. Only one of the subjects with hyperpepsinogenaemia $A$ had a pepsinogen $A: C$ ratio above the upper value of normal of $14 \cdot 1$ (see Fig 2).

To discriminate patients with ZollingerEllison syndrome from other subjects with hyperpepsinogenaemia $\mathrm{A}$ by the pepsinogen A:C ratio, the critical value is $4 \cdot 7$. This value is the mean of the group mean of Zollinger-Ellison patients (5.9) and the group mean of the other subjects together $(3 \cdot 5)$. Patients with Zollinger- 


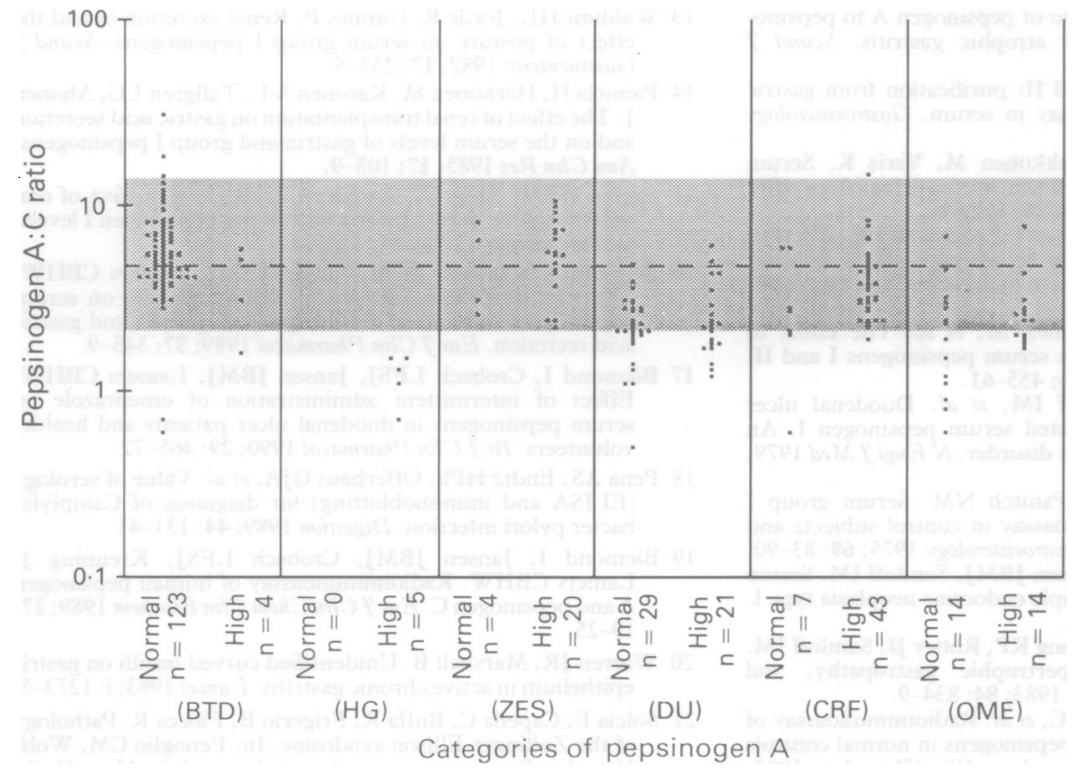

Figure 2: Shaded area: the normal range of the pepsinogen $A: C$ ratio $(2 \cdot 1-$ $14 \cdot 1)$. The subjects were grouped into normal (including low values) and high values $(>95 \mu g / l)$ of serum pepsinogen $A$. Values of the pepsinogen $A: C$ ratios of blood transfusion donors (BTD), of patients with hypertrophic gastropathy (HG), with ZollingerEllison syndrome (ZES) with duodenal ulcer $(D U)$, with chronic renal failure $(C R F)$, and of patients with reflux oesophagitis treated with omeprazole for three months $(O M E)$. The horizontal dashed line represents the critical value of $4 \cdot 7$ discriminating Zollinger-Ellison patients from other subjects with hyperpepsinogenaemia $A$.
Ellison syndrome had a significantly higher frequency $(70 \%)$ of pepsinogen $\mathrm{A}: \mathrm{C}$ ratios above 4.7 than all other groups of patients with hyperpepsinogenaemia A. Duodenal ulcer patients, chronic renal failure patients, and patients after three months omeprazole treatment had a frequency of A:C ratios greater than $4 \cdot 7$ of, respectively, $9 \cdot 5,25 \cdot 6$, and $7 \cdot 1 \%$.

\section{Discussion}

This study shows that in patients with hyperpepsinogenaemia A measurement of serum pepsinogen $\mathrm{C}$ concentrations may provide additional diagnostic information. Among the various groups studied, the differentiation between patients with hypertrophic gastropathy, Zollinger-Ellison syndrome, and those receiving omeprazole treatment for reflux oesophagitis is sometimes hard to make, because all these three groups often have, in addition to a high serum pepsinogen A value, dyspeptic complaints and hypergastrinaemia. Furthermore, the presence of large gastric folds and gastric protein loss is a feature of both hypertrophic gastropathy and the Zollinger-Ellison syndrome. The differentiation between these conditions is especially difficult if Zollinger-Ellison patients have a negative secretin provocation test and no obvious tumours shown by computed tomography. The differentiation between hypertrophic gastropathy and Zollinger-Ellison syndrome can readily be made by the serum pepsinogen $A: C$ ratio, as all five patients with hypertrophic gastropathy had a low, and all Zollinger-Ellison patients a normal ratio. The number of patients with hypertrophic gastropathy is small, however, and it is unknown whether the ratio is also helpful in the differentiation from other conditions with large gastric folds, such as linitis plastica and lymphosarcoma. The differentiation between patients with Zollinger-Ellison syndrome and those with omeprazole treatment for reflux oesophagitis cannot be made on the basis of the pepsinogen $\mathrm{A}: \mathrm{C}$ ratio, although a low ratio may suggest treatment with omeprazole and a pepsinogen $\mathrm{A}: \mathrm{C}$ ratio greater than $4 \cdot 7$ ZollingerEllison syndrome. The differentiation between
Zollinger-Ellison syndrome and duodenal ulcer is impossible by measurement of pepsinogen C, while a low pepsinogen $A: C$ ratio is found in about $40 \%$ of the duodenal ulcer patients and in none of the Zollinger-Ellison patients. A pepsinogen A:C ratio greater than 4.7 is found in $70 \%$ of the Zollinger-Ellison patients, but only twice in duodenal ulcer patients. Obviously, this differentiation can readily be made by measurement of serum gastrin. The results in patients with chronic renal failure are interesting, but clinically irrelevant. In the control group of blood transfusion donors we have excluded the patients with serological evidence of $H$ pylori infection, because of its association with chronic active gastritis..$^{20}$ As we did not perform endoscopy in this control group, we cannot rule out the inclusion of a few patients with gastritis. In particular, the low pepsinogen A concentration and pepsinogen $\mathrm{A}: \mathrm{C}$ ratio in two of the patients, may point to atrophic gastritis, ${ }^{1-3}$ which is supported by an increased gastrin concentration in one of them. ${ }^{2}$

The mechanism for the abnormal pepsinogen values in the various patient groups is not fully elucidated. The low pepsinogen $\mathrm{A}: \mathrm{C}$ ratio in patients with hypertrophic gastropathy is mainly caused by the extremely high concentrations of serum pepsinogen $C$ in these patients. Whether this low pepsinogen $\mathrm{A}: \mathrm{C}$ ratio is caused by hyperplasia of the mucous neck cells in the gastric body or inflammation of the antrum remains to be established. Patients with Zollinger-Ellison syndrome and raised concentrations of serum pepsinogen $A$ are often found to have high serum pepsinogen $C$ values. The reason for the high serum pepsinogen $C$ concentrations in this group is probably related to the trophic effect of gastrin on the oxyntic mucosa. In fact, hyperplasia of the oxyntic mucosa has been reported in the Zollinger-Ellison syndrome. ${ }^{21}$ The high pepsinogen $\mathrm{C}$ concentrations in patients with duodenal ulcer are probably related to $H$ pylori related chronic active gastritis. The cause of the high pepsinogen $C$ concentrations in patients on omeprazole treatment is unknown, but it may be due to a direct effect of omeprazole on the gastric mucosa ${ }^{15}$ to omeprazole induced hypergastrinaemia or bacterial overgrowth of the stomach because of acid inhibition. The high pepsinogen $\mathrm{C}$ concentrations in chronic renal failure are obviously due to impaired renal function.

In summary, measurement of serum pepsinogen $\mathrm{C}$ in hyperpepsinogenaemia $\mathrm{A}$ subjects yields additional diagnostic information for the diagnosis of hypertrophic gastropathy and the Zollinger-Ellison syndrome; a low pepsinogen A:C ratio may point to hypertrophic gastropathy and a pepsinogen $A: C$ ratio greater than $4 \cdot 7$ suggests Zollinger-Ellison syndrome.

1 Samloff IM, Varis K, Ihamaki T, Siurala M, Rotter JI. Relationships among serum pepsinogen I, serum pepsino-
gen II, and gastric mucosal histology. A study in relatives of patients with pernicious anaemia. Gastroenterology 1982; 83: patients

2 Westerveld BD, Pals G, Lamers CBHW, et al. Clinical significance of pepsinogen $A$ isozymogens, serum pepsino-
gen $A$ and $C$ levels, and serum gastrin levels. Cancer 1987 ; 5en $A$ and

3 Borch K, Axelsson CK, Halgreen H, Damkjaer Nielsen M, 
Ledin T, Szecsi PB. The ratio of pepsinogen A to pepsinogen C: a sensitive test for atrophic gastritis. Scand $\mathcal{f}$ Gastroenterol 1989;24:870-6.

4 Samloff IM. Pepsinogens I and II: purification from gastric mucosa and radioimmunoassay in serum. Gastroenterology 1982; 82: 26-33.

5 Sipponen P, Samloff IM, Saukkonen M, Varis K. Serum pepsinogens I and II and gastric mucosal histology after partial gastrectomy. Gut 1985; 26: 1179-82.

6 Feldman M, Blair AJ, Richardson CT, Samloff IM. Effect of proximal gastric vagotomy on serum pepsinogen I and II concentrations and acid secretion in duodenal ulcer patients. Dig Dis Sci 1988; 33: 824-7.

7 Peetsalu A, Tamm A, Härkönen $\mathrm{M}$, et al. The effect of vagotomy and antrectomy on serum pepsinogens I and II Scand F Gastroenterol 1990; 25: 455-61.

8 Rotter JI, Sones JQ, Samloff IM, et al. Duodenal ulcer disease associated with elevated serum pepsinogen I. An inherited autosomal dominant disorder. $N$ Englf $\mathcal{F}$ ed 1979 ; 300: 63-6.

9 Samloff IM, Liebman WM, Panitch NM. Serum group I pepsinogens by radioimmunoassay in control subjects an patients with peptic ulcer. Gastroenterology 1975; 69: 83-90.

10 Lamers CBHW, Rotter JI, Jansen JBMJ, Samloff IM. Serum pepsinogen I in familial multiple endocrine neoplasia type I. Dig Dis Sci 1988; 33: 1274

11 Lam SK, Hui WKK, Ho J, Wong KP, Rotter JI, Samloff IM Pachydermoperiostosis, hypertrophic gastropathy, and peptic ulcer. Gastroenterology 1983;84: 834-9.

12 Ichinose M, Miki K, Furihata C, et al. Radioimmunoassay of serum group I and group II pepsinogens in normal controls serum group I and group II pepsinogens in normal controls
and patients with various disorders. Clin Chim Acta 1982; 126: 183-91.
13 Waldum HL, Jorde R, Gunnes P. Renal excretion of and the effect of posture on serum group I pepsinogens. Scand $\mathcal{F}$ Gastroenterol 1982; 17: 253-5.

14 Paimela H, Härkönen M, Karonen S-L, Tallgren LG, Ahonen $J$. The effect of renal transplantation on gastric acid secretion and on the serum levels of gastrin and group I pepsinogens. Ann Clin Res 1985; 17: 105-9.

15 Festen HPM, Thijs JC, Lamers CBHW, et al. Effect of ora omeprazole on serum gastrin and serum pepsinogen I levels. omeprazole on serum gastrin and seru

16 Biemond I, Crobach LFSJ, Jansen JBMJ, Lamers CBHW Effect of short-term omeprazole administration on serum pepsinogens in relation to fasting serum gastrin and gastric acid secretion. Eur f Clin Pharmacol 1989; 37: 345-9.

17 Biemond I, Crobach LFSJ, Jansen JBMJ, Lamers CBHW. Effect of intermittent administration of omeprazole on serum pepsinogens in duodenal ulcer patients and healthy serum pepsinogens in duodenal ulcer patients and
volunteers. Brf Clin Pharmacol 1990; 29: 465-72.

18 Pena AS, Endtz HPh, Offerhaus GJA, et al. Value of serology (ELISA and immunoblotting) for diagnosis of Camplylobacter pylori infection. Digestion $1989 ; 44: 131-41$.

19 Biemond I, Jansen JBMJ, Crobach LFSJ, Kreuning J, Lamers CBHW. Radioimmunoassay of human pepsinogen A and pepsinogen C. Eurf Clin Chem Clin Biochem 1989;27 19-25.

20 Warren JR, Marshall B. Unidentified curved bacilli on gastric epithelium in active chronic gastritis. Lancet 1983; i: 1273-5.

21 Solcia E, Capella C, Buffa R, Frigerio B, Fiocca R. Pathology of the Zollinger-Ellison syndrome. In: Fenoglio CM, Wolf $\mathrm{M}$, eds. Progress in surgical pathology vol 1. New York: Masson, 1980: 119-33. 